\title{
Comunalidad, Guendaliza'a and anti-mine mobilizations in the Isthmus of Tehuantepec
}

\author{
Alessandro Morosin ${ }^{1}$ \\ University of San Diego, USA
}

\begin{abstract}
How do grassroots strategies for the defense of territory inter-relate with the "politics of time" in the early phases of socio-environmental struggles? This article addresses this question via ethnographic research and indepth interviews in Mexico's Isthmus of Tehuantepec. Opponents of mines and a Special Economic Zone (SEZ) in this region invoke comunalidad and Guendaliza'a - indigenous ways of life associated with mutual aid and territorial sovereignty. These values are enacted by networks of activists seeking to protect the land and livelihoods of future generations against global capitalism's drive for cheap raw materials. By rejecting dualist distinctions between Society and Nature, indigenous cosmovisions can help defensive movements forge alternatives to socio-environmental violence. Engaging with this case brings separate theoretical frameworks of defensive resistance, cheap nature, ecological-distribution conflicts, and indigenous cosmovisions into dialogue with one another.
\end{abstract}

Key words: social movements, indigenous peoples, global capitalism, ethnography, anti-mining

\section{Résumé}

Comment les stratégies de base pour la défense du territoire interagissent-elles avec la «politique du temps» dans les premières phases des luttes socio-environnementales? Cet article aborde cette question via des recherches ethnographiques et des entretiens approfondis dans l'isthme mexicain de Tehuantepec. Les opposants aux mines et à une zone économique spéciale (ZES) dans cette région invoquent comunalidad et la Guendaliza'a - modes de vie indigènes associés à l'entraide et à la souveraineté territoriale. Ces valeurs sont promulguées par des réseaux d'activistes cherchant à protéger les terres et les moyens de subsistance des générations futures contre la tendance du capitalisme mondial à acheter des matières premières bon marché. En rejetant les distinctions dualistes entre société et nature, les cosmovisions indigènes peuvent aider les mouvements défensifs à forger des alternatives à la violence socio-environnementale. S'engager dans ce cas amène des cadres théoriques distincts de résistance défensive, de nature bon marché, de conflits de distribution écologique et de cosmovisions indigènes dans un dialogue les uns avec les autres.

Mots-clés: mouvements sociaux, peuples autochtones, capitalisme mondial, ethnographie, anti-mines

\section{Resumen}

¿Cómo las estrategias comunitarias para la defensa del territorio se interrelacionan con la "política del tiempo" durante las fases tempranas de los conflictos socioambientales? Este artículo aborda este tema a través de investigación etnográfica y entrevistas a profundidad en el Istmo de Tehuantepec, en México. Los opositores a

\footnotetext{
${ }^{1}$ Dr. Alessandro Morosin, Visiting Assistant Professor, Department of Sociology, University of San Diego, USA. Email: amorosin "at" sandiego.edu. Acknowledgements: I am grateful to everyone who made this research project possible. Doña Lupita and Miguel Angel have been fantastic hosts. I wish to recognize all the activists who have worked with me, particularly Manuel and the Prepa, Daniel, Alejandro, Angeles, Ruben, and Paulina. Thank you to Dr. Paola Sesia, Salvador Aquino, and CIESAS Pacifico Sur for critiquing my work and inviting me to be a Tesista Huésped when I began fieldwork I appreciate the Blum Initiative on Global and Regional Poverty Studies for awarding me a Collaborative Research Grant. Gracias to each of my student interns at UC Riverside who assisted with translation and transcription of interviews. My dissertation committee members dedicated much of their time and attention to reading previous drafts. Finally, the editors of this special issue and anonymous reviewers at $J P E$ helped sharpen the theoretical framework of this case study significantly. This is the fifth article in Ashley Fent and Erik Kojola (eds.). 2020. "Political ecologies of time and temporality in resource extraction", Special Section of the Journal of Political Ecology 27: 819-938.
} 
las minas y a una Zona Económica Especial (SEZ) en esta región, recurren a la comunalidad y la Guendaliza'a -modos de vida indígenas asociados con apoyo mutuo y soberanía territorial. Estos valores representados por redes de activistas buscan proteger las tierras de futuras generaciones y formas de subsistencia en contra del capitalismo global que arrasa materias primas baratas. Al rechazar estas distinciones dualistas entre sociedad y naturaleza, las cosmovisiones indígenas pueden apoyar a movimientos de defensa para formular alternativas para la violencia socioambiental. El trabajo con este caso puede resultar en marcos teóricos específicos de oposición defensiva, naturaleza barata, conflictos de distribución ecológica y cosmovisiones indígenas dialogando entre ellas.

Palabras clave: movimientos sociales, poblaciones indígenas, capitalismo global, etnografía, oposición a la actividad minera

\section{Introduction}

A global "race" for natural resources (Bunker and Ciccantell 2005) has been impinging upon the lives of many rural and Indigenous communities around the globe who reside near mines and other large scale infrastructure projects (Bárcenas and Galicia 2011; Bebbington et al. 2008; Dunlap 2018b; Narchi 2014; Partridge 2017; Ramos 2012; Urkidi and Walter 2011; Veltmeyer and Bowles 2014; Veltmeyer and Petras 2014). Collective struggles in the name of "life", livelihoods and cultural identities (Toledo et al. 2015) have proliferated in relation to fundamental power inequities inherent in resource extraction (Porto and Pacheco 2009), particularly when the appropriation of resources and energy implicates larger ethnic or caste identities (Temper et al. 2015: 261). However, as pointed out by Tetreault et al. (2018: 6), these "objective conditions of environmental crisis and injustice" do not in and of themselves give rise to conflict and mobilization in all cases.

In what Tetreault et al. (2018: 26) call "defensive resistance", activist campaigns work to prevent "potential negative social and environmental outcomes" that are "likely to occur" as result of some economic activity that is localized in a particular place (Temper et al. 2015: 262), but whose construction has not yet begun. ${ }^{2}$ Over the past decade, owing largely to the prior liberalization of Mexico's mining sector and to the North American Free Trade Agreement (NAFTA), mining and raw materials extraction have taken new leaps throughout Mexico (Heidrich 2016), particularly as the sector has been penetrated by numerous Canadian mining firms. Defensive mobilizations attempting to block extractive projects before they can begin now characterize 70 percent of anti-mine movements in Mexico (Tetreault 2019: 91).

This article examines how Indigenous cosmovisions can influence not only defensive strategies for the prevention of new metal mines, but also generate coherent alternatives to a pernicious "extractive" development model that devalues people and nature (Gudynas 2009). As part of the incipient movement against the Special Economic Zone (SEZ) in the Mexican state of Oaxaca (2015-2017), activists from different tendencies and walks of life coalesced in collective action aimed at preventing the establishment of open-pit mines in agricultural and semi-rural areas of the Isthmus of Tehuantepec region (also known as el Istmo, Figure 1). This region of Southern Mexico has no significant history of large-scale metal mining. As the first political ecology study on this recent anti-mine movement, this article contributes to answering "why these conflicts arise in some local and regional contexts and not in others", and can increase our understanding of "how social environmental movements [are] constructed and sustained" (Tetreault et al. 2018: 5).

Over a short period of time, a plethora of organizations have been fomenting pan-Indigenous activism against the federally decreed Isthmus SEZ. This project links the Oaxacan Isthmus with the state of Veracruz in an inter-oceanic hub of trade and raw materials extraction. Various activists in communities directly adjacent to mining concessions (such as Ciudad Ixtepec, San Francisco Ixhuatán, and Santo Domingo Zanatepec) are affiliated with a new coalition known as APOYO, or Articulation of Original Peoples of the Oaxacan Isthmus

\footnotetext{
${ }^{2}$ As a response to an event or policy that has yet to occur, defensive action against mining projects should not be confused with what other social movement scholars call "spontaneous" protest (Snow and Moss 2014: 2).
} 
in Defense of Territory (APOYO 2017). They view mining as the most destructive of all megaprojects that the SEZ would bring to the Isthmus (Delgado 2002).

The link between natural resource extraction and armed violence on a global scale has become more empirically established due to increased scholarly work in this area (Downey et al. 2010), and also by recent reports documenting how scores of environmental activists in the Global South have been murdered for organizing against resource extraction (e.g. Global Witness 2014). In the midst of heightened drug-related violence and the risk of state/paramilitary repression (Morosin 2019, 2020), why would everyday people risk their safety to join a protest movement against mining, even before a single mine has been installed?

Although not all movement participants agree on ontology and tactics, they draw on pre-existing notions of natural spaces as a vital part of the region's ancestral patrimony. These ideas are reinforced and amplified by recent "networks of resistance" (Tetreault 2018: 23). As in many similar cases around the world, this mobilization tends to consist of "coordinated, non-violent territorial resistance by Indigenous and campesino communities, supported by continuing and resurgent social movements and civil society networks, and global solidarity initiatives" (Rocheleau 2015: 706). Comparably, Moises Arce (2014) outlines regional anti-mine movements in Peru. In the Isthmus of Tehuantepec, networks of anti-mine actors in the Isthmus include Catholic liberation theologists, human rights groups, environmental civil society organizations, small ranchers, youth, community radio broadcasters, ejidos, teachers, and some municipal mayors (in name, at least). These networks were made possible by, and further build upon, prior organizing in the region, such as an intense anti-wind energy park movement from the late 1990s to the present day (e.g. Ávila-Calero 2017; Dunlap 2018d; Lucio 2018), and Zapotec movements for self-determination that have been centered in Juchitán since the 1970s (Campbell et al. 1993). The strategies of these contemporary activist networks mirror what Stuart Kirsch calls "the new politics of time", where activists avoid contesting operational mines and instead focus on targeting projects that are still in the planning stage. This preventive strategy can "make it difficult for the mining company to raise the necessary capital or receive government approval" (Kirsch 2014: 191).

My central argument is that by channeling Indigenous cosmovisions and values into alternatives that are more congruent with the past, present and desired future life of this multi-ethnic region, Indigenous defensive resistance in the Isthmus of Tehuantepec applies the politics of time in ways that can slow or stall capital's commodification of lands and nature. Local, regional, national and transnational organizations have helped transform what might have remained "localized, segmented outbursts" (Arce 2014: 65) into a regional movement with considerable outside support. A leading current of this movement is motivated by their interpretations of comunalidad and Guendaliza'a-Indigenous communal norms that inspire broad sympathy and participation of residents. With the assistance of outside organizations such as Ojo de Agua Comunicación and the Mexican Network of People Affected by Mining (REMA), anti-mine networks cohered a very large "no to mining" march in the normally quiet town of Zanatepec, while anti-mine activism in Ixtepec has been frequent and robust. Even though the term comunalidad originated not in the Isthmus but in the Sierra Juarez (Luna 2010), it is being adapted and applied by movement organizers to oppose the expansion of the mining frontier into other Indigenous territories. Since these demands are difficult for the dominant economic and political system to accommodate, this ongoing case is likely to affect national politics in Mexico (Arce 2014, 2016).

This article proceeds as follows. A theoretical section explains how Special Economic Zones embody the extension of commodity frontiers and the race for cheap nature. I then discuss how local property rights and the legacy of agrarian reform influence contemporary mobilization strategies in the Istmo. I review how Indigenous worldviews of comunalidad and Guendaliza'a have come to animate defensive resistance campaigns in the Isthmus. This is followed by a brief discussion of my research methodology. The article's main empirical narrative consists of thick description of three separate movement encounters in two Tehuantepec Isthmus towns, interspersed with interview quotes. I conclude by discussing some broader implications and lessons for political ecology about the fusion of Indigenous cosmovisions into anti-extraction movements. 


\section{Special Economic Zones: opening commodity frontiers for the "four cheaps"}

As argued by David Pellow (2017), environmental violence is predicated upon, and can be seen as another form of, social violence. Thus, it is vital to learn from social movements who are maneuvering to challenge policies and systems that are ecocidal and potentially genocidal (Wolfe 2006: 387). Extractive firms have been expanding into marginal sources of minerals and energy due to resource depletion, as well as increased demand and profitability. As is becoming well known, the rate of raw materials extraction from Latin America to the USA (and increasingly to China) quadrupled from 1970 to 2008, especially during the commodities boom of the early 2000's (Martínez Alier and Walter 2016). This process is part of historical capitalism's unceasing geographic extension into new commodity frontiers (Moore 2000) as well as the intensified exploitation of existing energy and mineral reserves. As chemically intensive open-pit mining for gold and silver in relatively isolated regions of Mexico expands the "mining frontier", Mexico has become one of the world's top destinations for foreign direct investment in mineral exploration (Tetreault 2019).

As a development policy, SEZs aptly reflect the tendency for capital to appropriate the territories and spaces that previously existed on the margins/peripheries of the world-system (Harvey 2001). While introducing institutional reforms at multiple spatial levels (national, regional, municipal, etc.), SEZs intensify existing capitalist markets and production relations (Sigler 2014). This is particularly evident in how they subordinate the use and extraction of raw materials to a global commercial logic that disadvantages smallholders and peripheral regions as a whole. Often introduced by neoliberal elites in an opaque or undemocratic manner, SEZs are a means for transnational corporations to secure what Moore (e.g. 2010; 2011) calls the "four cheaps": cheap food, fuel, labor, and energy that economic expansion depends upon. While this is welcomed as progress by states, investors, and others who stand to gain short-term rents and profits, it is more frequently interpreted as a form of communal and ecological annihilation by campesinos (peasants) and other rural peoples.

Analysts like Victor Toledo have used the language of ecocide and civilizational crisis to raise consciousness about how the "appropriation, transformation, consumption, and excretion" of natural resources has been brought to dangerously unsustainable levels (Toledo 2015: 27). Relatedly, it has been pointed out that destructive methods of energy production "renew and advance the colonial genocide process by continuing to assimilate and target (Indigenous) people who continue to value their land, culture, and relationships" (Dunlap 2018c: 552, parentheses in original).

Mexico's Isthmus of Tehuantepec, the shortest distance between the Gulf of Mexico and the Pacific Ocean, epitomizes how SEZs and new mining concessions threaten to accelerate dispossession of Indigenous lands and livelihoods (Morosin 2019). At the same, the Isthmus also illustrates the potential for reducing or halting the socio-environmental violence of megaprojects through sustained mobilization around alternative cosmovisions. Due to its geostrategic importance and richness in raw materials, the Isthmus has long been coveted by national and global elites (Binford 1985). For at least two decades, the Mexican state has been extracting and trading oil, timber, wind energy, and other resources in this area (Wilson 2014). The federal law to create SEZs was enacted by the Mexican Congress in 2015 as a plan to attract foreign investment and trade to several of Mexico's "underdeveloped" southern states through generous corporate tax incentives (Harrup 2016). The Isthmus SEZ, sometimes referred to in official terms as the Trans-Isthmus Corridor (Rodriguez 2017) or Inter-Oceanic Corridor, is one of these three SEZs. While planning was underway under the presidency of Enrique Peña Nieto, the Mexican government pledged US\$5.3 billion ( $\$ 115$ billion pesos) for the project (Álvarez Martínez and Aguirre Ochoa 2017).

Since political ecology is one form of "activist knowledge" (Escobar 2008), it is well-positioned to bring about "collaboration between environmentalists and scientists" that "empowers local organizations" to assert their rights (Tempe et al. 2015: 259). Activist knowledge can be generated once we understand how particular cosmovisions (Escobar 2006) may serve to strengthen defensive resistance to capital's relentless cheapening of nature. The particular Indigenous cosmovsions studied in this article help challenge the enduring ideological separation of Society from Nature - a dualist fiction which has seduced many movements of resistance to sever social emancipation from environmental sustainability (Moore 2015). The movements I profile in this piece are 
promising precisely because they avoid such tropes and traps. They insist upon social justice, cultural autonomy, and ecological preservation.

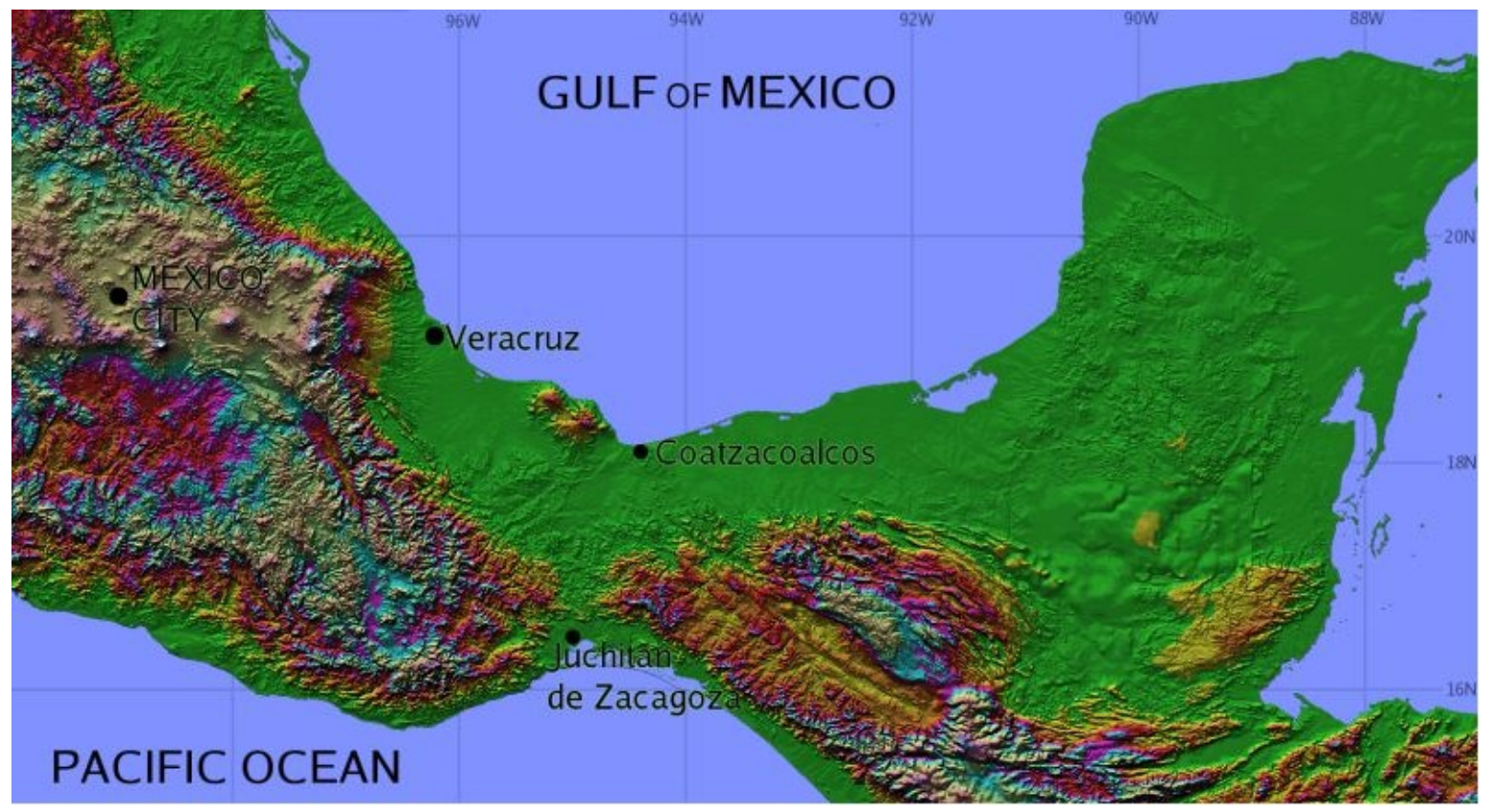

Figure 1: Isthmus of Tehuantepec. Source: Wikimedia Commons.

\section{Land tenure and socio-environmental conflicts in Mexico}

I use the term "socio-environmental conflicts" because this is the terminology employed by my respondents in Oaxaca, and by many Latin American researchers. These movements tend to combine ecological issues with distributional concerns for the material livelihoods of poor and marginalized people (Tetreault 2015). After a series of neoliberal reforms impacting land tenure, energy policies and the mining sector, socioenvironmental movements have multiplied, especially in Mexico's rural areas. Political ecology interprets these conflicts by focusing on power relations between groups of people that shape (and are shaped by) phenomena in the non-human natural world (Martinez-Alier et al. 2011, 2010).

Government policies since the 1970s began a complex process of privatizing and liberalizing Mexico's economy and society. Under Mexican President Carlos Salinas, this culminated in the reform of Constitution Article 27 in 1992 in order to coincide with NAFTA. While immediately affecting about 50 percent of Mexico's national territory, this constitutional reform effectively "ends the government's obligation to redistribute land to the landless and permits (but does not require) the privatization of land in non-alienable corporate status as ejido or communal land" (Stephen 1997: 77).

Just over half of all property in Mexico is "social property", comprised of ejidos and comunidades. Ejidos represent 42.9 percent of national land area held by 3,844,601 beneficiaries, while comunidades represent 8.7 percent of national land area held by 608,367 beneficiaries. Additionally, 37 percent of Mexican land is held privately and 11 percent is classified as public property (data from Bárcenas 2017). Communal lands were granted to Mexico's Indigenous communities by the Spanish Crown after the Spanish Conquest of the Aztec empire in the early 16th century, and still exist despite being legally abolished in the mid-19th century. Ejido property has its origins in the political demands of the peasantry during the 1910 Mexican Revolution. Ejidatarios/as still today have usufruct rights over land parcels that are government controlled by the National Agrarian Registry. 
The state of Oaxaca can be seen as a stubborn holdout in Mexico's long-running abandonment of agrarian reform. A clear majority of municipalities in the state oppose privatizing and "titling" their lands (Nahmad et al. 2011). Oaxaca's adherence to norms of social landownership that are more or less directly managed by the campesino sector are unique to much of Latin America and the world. These traditions of communal landownership pose institutional barriers to mining exploration and other state-supported infrastructure projects. Furthermore, Oaxaca has a much larger portion of social property than the national average: 78 percent of land in the state is held collectively, mostly by indigenous "comunidades" (Payan and Correa-Cabrera 2014). The juridical status of much of the agrarian terrain in the Isthmus where I performed my fieldwork is communal, but with variation. Zanatepec has both ejidos and communal lands, while Ixtepec's farming and grazing lands are all communal.

Over the past two decades, Mexico's presidential administrations have approved mineral exploration concessions that lease a quarter of the country's national territory (50 million hectares) to mining activity for decades to come. Federal ministries awarded 344 mining contracts in the largely Indigenous state of Oaxaca from 2002 to 2011 alone (Toledo et al. 2015: 138). Toxic contamination of rivers and soil by mining-related chemicals has provoked public health crises (Dore 2000).

The legality and legitimacy of these mining projects remains in dispute. Francisco López Bárcenas, a Oaxacan historian and legal advisor to anti-mining movements throughout Mexico, details how the Mexican nation-state has the authority to grant use of its land and waters to private owners as well as social owners (e.g. ejidatarios). However, that land cannot be expropriated from the latter without the permission of the assembly of local producers who hold titles (Bárcenas 2017).

Mining companies and their representatives have been approaching ejidatarios and comuneros throughout Mexico with a mixture of bribes, incomplete information about risks, and outright threats in order to appropriate land for the extraction of precious metals (Tetreault 2016). While some rural communities throughout Mexico have supported mining in hopes of jobs and investment, many have turned against mining projects. Active Canadian-owned mines in Oaxaca's Sierra Norte (Aquino Centeno 2013; Barkin 2013) and Central Valley (Hortensia 2014) have sparked mass protests in recent years, and some leaders of these movements have been killed or injured by paramilitary attacks (Matias 2016).

In sum, this abrupt expansion of the "mining frontier" revives neocolonial forms of governance that deny Indigenous people's existence. Mexico's expansion of open-pit mining reinforces the ethno-centric character of Latin American nation-states that was critiqued by the late Mexican anthropologist Rodolfo Stavenhagen:

The ideology of national culture has produced, on many occasions, the subordination of and discrimination against ethnic minority groups and the denial of their cultural rights (and frequently also their most basic human rights). Many countries have adopted policies of forced assimilation... in the name of the ideology of national culture...Customs and traditions that form part of the cultural heritage of subordinate ethnic groups are forbidden...Their history is condemned to oblivion and their identity is denied in a thousand ways. (Stavenhagen 1983: 11)

Indigenous anti-mine activists are conscious of colonialism's long shadow, and their own worldviews attempt to deter both the state's denial of cultural rights as well as capitalism's commodification of nature.

\section{Indigenous ontologies, defensive resistance, and temporalities}

For those rural and Indigenous peoples who tend to rely on collective forms of land tenure, and who still uphold norms of reciprocity in social and political life, the pressure to rent one's communal property to a mining firm often throws up "ecological-distribution conflicts" by negating cultural rights and identities (MartinezAlier et al. 2010). This occurs when these communities' distinct ways of understanding nature clash with the "calculative rationality and monetized accounting practices" that are used by the state and transnational corporations (Sullivan 2017: 232). More recently, Mario Blaser (e.g. 2013: 25) cautions against reducing these ecological-distribution conflicts to "just another cultural perspective." Similarly, Sian Sullivan (2017) has 
argued that sensitivity to diverse cultural understandings of nature can sharpen political ecology's analytical power.

As one interesting reference case for these arguments, the Tehuantepec Isthmus bears out a "regional dynamic" of ecological-distribution conflicts owing to how its "communitarian institutions and practices prevail over state and private property logics" (Ávila-Calero 2017: 1001). Isthmus Zapotecs have a long and complex history of contesting external domination, such as a 1911 revolt against the dictatorship of Porfirio Diaz (Jimenez Lopez 2015), opposition to the land grabs of the Spanish colonizers (Binford 1985) and even resisting an attempted Aztec invasion in 1492 (González Licón 1990). When parts of the Isthmus threatened to secede from Mexico in 1851 (Campbell 1994), state and federal authorities intervened to suppress the rebellion, which only reinforced a longstanding suspicion of federal power. Social conflicts between landowners, political elites, and rebel movements have been fought over ejidos and communal lands in the Istmo for at least one hundred years (Binford 1985).

More recently, the COCEI (Coalition of Workers, Peasants, and Students of the Isthmus) was a radical movement and political party of considerable influence. Formed in the late 1970s in the Zapotec town of Juchitán (Figure 1), COCEI emphasized labor and land rights, as well as Zapotec identity (Campbell et al. 1993). The COCEI briefly held municipal power in Juchitán in 1981 in coalition with the Mexican Communist Party, making Juchitán the only province to unseat Mexico's ruling Institutional Party of the Revolution (PRI) in the 1980s.

These experiences and memories of resistance (Manzo 2008) have given rise to "empowering beliefs and behaviors" (Morris 1992: 363) that figure prominently in the region's quotidian lifeworld. Many of the movement activists I met had been young COCEI partisans during the 1970s and 1980s, and others were sons and daughters of these veteran freedom fighters. In this sense, regional resistance against the threat of mines is a generational extension of past struggles to reclaim land from large landowners. Today, unlike the COCEI of the 1980s, the movement for defense of Isthmus territory and against mining couches its appeals and programmatic declarations in terms of the rights of Indigenous people everywhere to have their land and customs respected. But like the early COCEI, today's activist networks also speak in the name of peasants and the poor.

Movement organizers in Oaxaca's Isthmus creatively apply cultural ideas and practices that have continued to make life mutually possible for Isthmenians, such as the insistence that the social community is a part of nature. Although these organizers do not openly call for the overthrow of capital and imperialism per $s e$, such views are still antithetical to modern capitalism's aforementioned Nature-Society dualism and its dynamic of endless accumulation. At the same time, this movement is not necessarily "pre-figurative" (Leach 2013) because its participants are not attempting to create "experimental or alternative social arrangements" that will fully replace those of the existing society (Yates 2014). The lifestyle its members claim to want is precisely the one they're still practicing now, or that they practiced until neoliberal policies began to penetrate the region relatively recently. Indigenous cultures have various names to refer to this "way of life." Comunalidad and Guendaliza'a provide meaning to the interaction between the social and natural world, and they undergird campesino/Indigenous movements against resource extraction.

The idea of comunalidad (literally, "communality") was originally and quintessentially applied to the Zapotec and Mixe (ayuujk) ethnic groups of Oaxaca's Sierra Norte region by anthropologists who originated from that area (e.g. Luna 2010; Díaz, Hernández, and Jiménez 2007; Gómez 2001). The term denotes the forms of reciprocity that structure the organization of these communities, such as voluntary labor in local works projects (tequio) and unpaid political leadership positions elected by local assemblies (cargos). Comunalidad has been called an "indigenous analytical theory" and a "neo-indigenist current" (Acosta 2014: 15). According to this perspective, the different communities who make up an ethnic pueblo are united by common "language, territorial extensions, and awareness of collective identities" (Maldonado 2010: 12).

Just as the ethnic Mixe/ayuujk people of Oaxaca use the term Wejën Kajën (Acosta 2014, Vásquez 2014), Zapotecs of the Isthmus speak of Guendaliza'a, meaning "obligations to one's relationships" (Altamirano-Jiménez 2013: 196). These ontologies entail a mode of relating to nature that permits renovation and conservation of natural resources (Acosta 2014). By looking at mining-related conflicts in the Isthmus, we 
can further appreciate that comunalidad is not an exclusive quality of Oaxaca's Sierra Norte highlands, nor of any particular ethnic group: "It is also present in rural non-indigenous communities that are governed by reciprocity.... and that hold land communally. Indigenous people are distinguished by their ethno-cultural elements: language, a pre-hispanic cosmovision and associated rituals, and the use of distinctive dress, among others" (Maldonado 2003).

There is also a temporal aspect. Comunalidad has a non-linear understanding of time as punctuated by ruptures and regressions. It invokes consciousness of a colonial past and seeks to re-establish a link with the negated histories of colonized peoples. Instead of fashioning a return to "ancient pre-hispanic empires", or a complete reversal of Western culture, comunalidad seeks to arrive at a balance where manifold ontologies and forms of development can co-exist (Acosta 2014: 46). Theorists emphasize three essential principles of comunalidad: land as the beginning and end of all forms of life; community as a human creation, and communal work (Díaz, Hernández, and Jiménez 2007). According to this schema, natural resources are conserved and enjoyed in common (Rendón Monzón 2003) and the existence of Indigenous peoples is affirmed in spite of multiple forms of domination. For these reasons, Fuente Carrasco (2012: 33) sees comunalidad as a critical strategy for building alternatives to the crisis of the Western civilizational project (Toledo 2015).

In the years since the 1994 Zapatista (EZLN) uprising, comunalidad has been adopted by various Zapotec intellectuals of the Tehuantepec Isthmus (e.g. Manzo 2011). Within the struggles of ecological valuation occurring there, those actors who talk about Guendaliza'a as well as comunalidad tend to see SEZs and mines not as economic opportunities, but as threats to their existence.

\section{Emergence of anti-mine mobilization in the Istmo}

The arrival of previously unseen levels of FDI in mineral exploration to the Isthmus represents an expansion of the mining frontier into one of Mexico's most culturally varied, ecologically diverse and juridically complex regions. After several mining contracts were granted to mostly Canadian-based corporations by Mexico's federal Ministry of Economy since 2011, exploration for gold and silver began near the towns of Ixtepec and Zanatepec without community knowledge. At the time of writing, no mining company has gained permission from the agrarian sector (campesinos and ranchers), or from the local and municipal governments, to actually begin mine operations.

In 2006, the Mexican Geological Service (SGM) discovered gold, copper, silver and zinc on communal low-lying mountain lands pertaining to the small city of Ciudad Ixtepec while mapping the region's geological profile. Plata Real, a subsidiary of the Canadian corporation Linear Gold, obtained 50-year exploration rights in 2008 from the Ministry of Economy in a mountainous section of Ixtepec's territory (Gomez Lima 2016). In 2014 the Comisariado de Bienes Comunales (the Communal Lands Commission in Ixtepec), a campesino body representing some 900 farmers on 30,000 hectares of communal land, denied permission for further exploration, but the government later expanded the contract to encompass 8,150 hectares, or 30 percent of Ixtepec's area (Chaca 2016). The Comité Ixtepecano Vida Territorio formed in 2016 in Ixtepec as an explicitly anti-mining movement claiming to represent all Ixtepecans, regardless of class, occupation, and status. They are part of the umbrella coalition APOYO, which has been coordinating resistance to mining concessions within the Isthmus SEZ since it formed in 2016.

On July 11 of 2016, dozens of residents of Ixtepec's different barrios traveled by car caravan into the hills where Plata Real had been exploring. They destroyed the company's six concrete landmarks that read "232089" (the number of the exploration contract) and "Lote Niza" (the name of the mining project). Activist media reports as well as mainstream press highlighted how women wielded heavy crowbars against these landmarks. This symbolic message to the government signaled that Ixtepec would resist any mining project on their lands. Pictures showed a 73-year old Zapotec woman and a young boy smashing the small concrete columns that previously demarcated the land on which Plata Real was operating. This grounded the resistance in the dignity of the Istmo's prototypically feminine, matrifocal culture (Chiñas 1992). According to this framing, "indigenous" (not just Zapotec) women are prominent in direct actions to defend "mother earth" and to deny the mining companies permission to operate. At the time, the Comité Ixtepecano declared "The inhabitants of Ixtepec were not informed nor consulted about mineral exploration in the area, which aims to 
extract gold, steel, copper, and zinc. This is detrimental to the health of the population and will contaminate the water, land and air" (SIPAZ 2016). In December 2016, the Comité self-published a summation of their activism that compiled their past nine months of anti-mine work, citing the media coverage that these actions generated (Comité Ixtepecano 2016).

A similar process of mining prospection has taken place in the south-eastern Isthmus without public knowledge. Between 2008 and 2013, the Dirección General de Regulación Minera (General Direction of Mining Regulation) of Mexico's Ministry of Economy awarded five different exploration contracts for gold, copper and zinc in the eastern tip of Oaxaca state, near Chiapas. This mining project, with two concessions north of Santo Domingo Zanatepec and three to the east near the town of Tapanatepec, would affect 30,000 hectares of Indigenous territory if the companies receive the permits to begin exploitation of minerals. Though registered company names are often changing (Minera Salamera, Minera Cascabel, etc.), the Canadian mining giant Minaurum Gold has rights to some of this mining project (Chaca 2015).

Alejandro Cruz Velasquez founded the Grupo Ecologista Zanatepec/ Zanatepec Environmental Group (hereafter GEZ - a member group of APOYO) and has been its Director since 2011. A native of Zanatepec, he is of campesino background and Zapotec ancestry. According to Alejandro and other GEZ activists, since no municipal authority had ever sought the consent of Zanatepec's agrarian sector or its people to conduct mineral exploration, the project violates the law.

In San Francisco Ixhuatán, teachers and students of the Preparatoria Jose Martí high school have worked to raise public consciousness throughout the region about mining and related issues of socio-environmental rights for ethnic Zapotecs and Ikoots for a number of years (Escalón Portilla and González Gaudiano 2017). The Coordinator of this small high school, Manuel Antonio Ruiz, tells me he discovered mining concessions just north of Zanatepec in 2014 by accessing the Ministry of Economy's website. The school and the GEZ partnered in 2016 to conduct systematic community outreach to residents. Combined with the new aforementioned networks formed in Ixtepec around the same time, socio-environmental activism in the Isthmus (e.g. Ávila-Calero 2017; Dunlap 2018a; Lucio 2016) began to assume anti-mine positions and gained closer links with anti-mine NGOs who advise communities throughout the Mexican republic. APOYO opposes opening these 70,000 hectares of Ishmus land to mining exploitation, and works to inform residents about the federal government's granting of mining exploration permits to transnationals such as Gold Resource Corp, First Mining Gold Corp, Minaurum Gold Inc., Oz Metals, and Acapulco Gold Corp (Manzo 2018).

\section{Data and methods}

I acquired the data for this article through ethnographic and participatory observation fieldwork, principally in the towns of Ciudad Ixtepec, San Francisco Ixhuatán, and Santo Domingo Zanatepec. Between September 2016 and March 2017, I conducted 53 digitally recorded, semi-structured interviews in Spanish with a purposive sample of consenting adult participants in Oaxaca's anti-mine movements (32 men, 21 women). The majority of these interviews lasted over an hour, and were later transcribed. I selected this site and targeted these participants out of a desire to document their motivations for anti-mine activism. My ethnographic observation of "interactions, understandings, and talk" among participants at varying levels of involvement (Benford 1997: 421) served to guide my inquiry on how Indigenous discourses like comunalidad had diffused from other contexts (Aquino Centeno 2013) to the Istmo, and the role that these notions have played in defensive campaigns.

I began the research in Oaxaca City with NGOs that introduced me to organizations in the Istmo that would become the key actors in my case. The fieldwork utilized snowball sampling (Atkinson and Flint 2001) to locate networks of respondents while I attended numerous public events such as forums, workshops, meetings, cultural programs, and an anti-mining march in Zanatepec on November 20, 2016 that drew several thousand marchers onto the Pan-American Freeway (Manzo 2016, Figure 2). I introduced myself to participants as a U.S.-based sociologist who was writing about mining-related conflicts in Mexico, and declared my intention to publicize their struggle. My own history of involvement in social movements allowed me to have a certain "insider" status among activists, but my positionality as an "outsider" was also reinforced by my status as a U.S. researcher who had very limited prior experience with Oaxaca's social context. While I was 
volunteering at meetings and events, many of my respondents eventually came to view me as a friend and opened their homes to me. I have since contributed to their fundraising efforts, signed and circulated petitions, and shared my writing with as many participants as possible. This approach seemed to narrow some of the social distance between myself and the main participants over time.

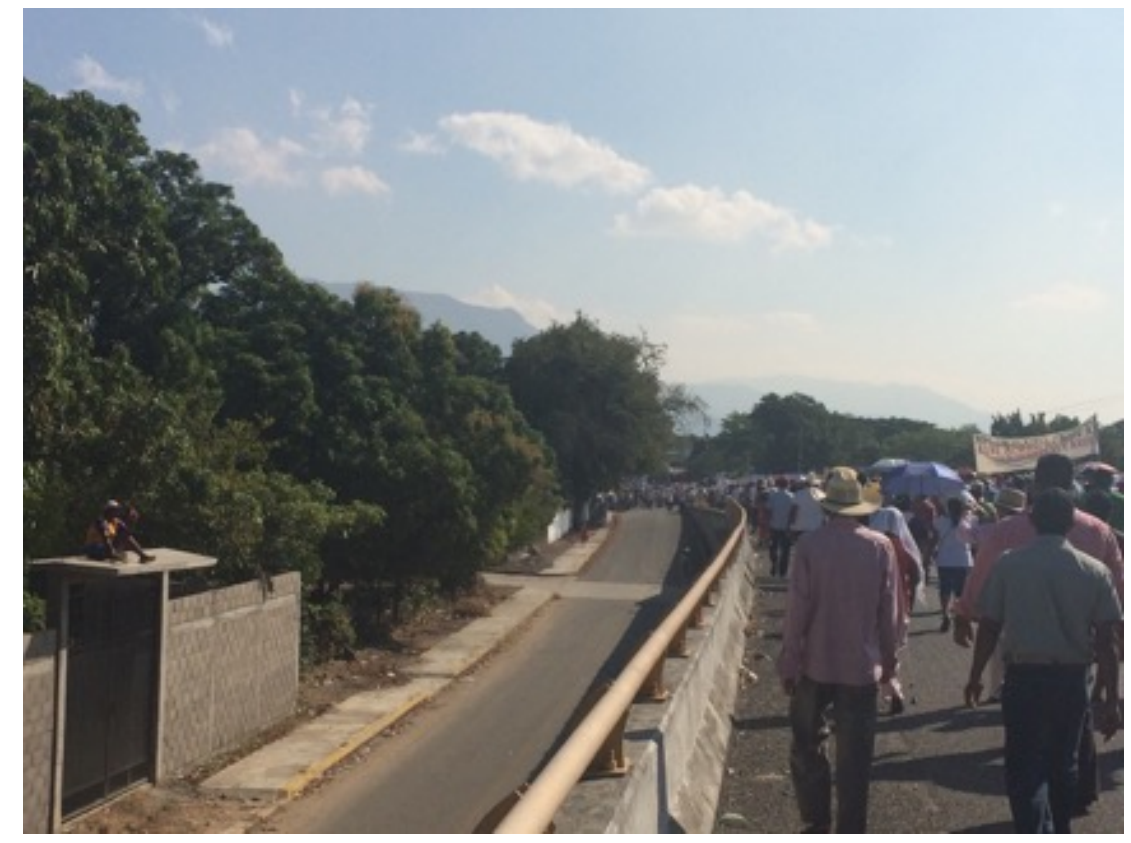

Figure 2: Mega-march against mining in Zanatepec on Panamerican Highway. Photograph by Author.

The logic of inquiry was interpretive and deductive. Whether I was having informal conversations at typical social events (fiestas, velas), attending a meeting, or interviewing campesinos, teachers and NGO members in their homes, I sought to "capture the worlds of the people by describing their situations, thoughts, feelings and actions and by relying on portraying the research participants' lives and voices" (Charmaz 2004: 499). All interviewees quoted in this article preferred to give their actual names rather than remain anonymous. Since many are already publicly identifiable figures whose campaigns have been publicly reported upon, I decided to honor their desire to be named (Guenther 2009).

\section{Cultural survival and communal lands_-a matter of "life" and death}

As is often the case with state-supported megaprojects, local populations chronically lack objective information on how foreign investments in wind energy, oil pipelines, mining and other projects associated with the incoming SEZ will affect them socially, culturally, economically and ecologically. In this section, I illustrate how these coalitions combine the politics of time (Kirsch 2014) with Oaxacan and Indigenous cosmovisions of life (la vida) in order to delay, prevent and block new mining projects in their territories. The opposition has been "scaled up" to include broader stakeholders partly thanks to how the performance and discourse of comunalidad appeals to multiple sections of people.

\section{Identifying threats to local producers}

The eastern Isthmus of Tehuantepec has earned the title of "Oaxaca's mango capital." Mango growers believe that the Isthmus stands to lose its major competitive advantage as Mexico's largest exporters of mangoes if it becomes a mining region (Fresh Plaza 2016). Zanatepec is one of several mango-producing municipalities 
of the Isthmus. Roberto Gamboa is a local mango farmer with extensive experience in anti-mining and human rights work who has advised and shaped the local movement since its inception. He channels political support for Zanatepec's anti-mine campesinos via the National Network of Mexicans Affected by Mining (REMA), a group which supports anti-mine movements in Mexico and Latin America. As president of Zanatepec's newly formed Union of Ejidos, Gamboa argues that without the permission of the agrarian sector, mining companies do not have the legal right to begin exploration and extraction. Hence, he works to unite all campesinos and ganaderos (livestock farmers) into an anti-mining bloc that can close off agricultural lands to any mining activity:

Look, with mines, the minerals belong to the nation. They're administered by the government, which gives the companies a permit, right? But the mineral is underneath the ground. The owners of the territory are comuneros and ejidatarios. To extract this mineral, the companies need legal permission, so the government gives a contract so that the nation's property [the minerals] can be extracted. But the land is not property of the nation; it's property of los pueblos [rural/Indigenous communities]. The government's goal is that social property in land gets privatized little by little... (Roberto Gamboa interview)

In Zanatepec's large march against mines that was previously mentioned, tensions emerged when the municipal president joined the march with his supporters openly brandishing their party colors, but then led a separate breakaway march that did not join people who were marching on the freeway. Many activists, including Gamboa, viewed this as a divisive betrayal of what should have been a "campesino's march", without the open presence of political parties.

Daniel García Toledo is President of Ejido Rio Manzo in Zanatepec, a small ejido with 26 members and 180 hectares. Toldeo informed me that unions of ejidos are larger agrarian organizations that are being built in San Miguel Chimalapa, Tapanatepec, Zanatepec, Ixhuatán, Reforma de Pineda, Niltepec, and Chahuites as an arm of defense against mining projects.

Comunalidad embraces such agrarian cooperation, but also extends beyond it. Alejandro of the GEZ marshals his early memories with the Ostuta River as he recounts the origins of his nickname. When I asked what shaped his identity into that of an environmentalist, he answered:

I was born on a ranch. Our origin is 100 percent campesino, and we have a sentimental relation with nature. The river would flow 20 meters from the ranch. Every day, we would live off of nature. We would eat from the fields and the river. We created a dependency, a spiritual relation with nature. And later, with the passing of time, this made me observe that form of life and that nature, which I wasn't conscious of during my childhood. We learned that nature was being harmed. It wasn't being looked after.

My family was large. Every day we depended on the land and the river. I personally feel a profound sense of veneration for the river because it fed me and my siblings. My nickname is Pescador (fisherman). For me this is an honor because it suggests my contribution to the household. I would catch fish from the river and bring them home, daily, so that we could all eat. And when there was some left over, I would put it on a plate and sell whatever could be sold to the neighborhood. And so even when I later left the pueblo to study in Mexico City, I brought with me this sense that things in nature are being disturbed. (Interview with Alejandro Cruz Velasquez).

The Ostuta river flows through communities like Ixhuatán and Zanatepec, and its waters would likely be diverted and polluted to support water-intensive mining activity that is currently being planned by mining companies in partnership with the Mexican state. Supported by larger networks like REMA, the Grupo Ecologista Zanatepec and unions of ejidos/ bienes comunales pressured the municipal government in February 
2019 to declare Zanatepec a pueblo libre de minería (mine-free community) by passing a formal legal act (acto de cabildo abierto) that forbids mineral exploration or exploitation. Like the growing number of "community referenda" in Latin America, these local acts are intended to "contest the authority of the state to grant mining licenses or otherwise promote large-scale development projects in rural areas" (Kirsch 2014: 211).

The GEZ are now protesting that a relative handful of residents of La Cristalina, a small jurisdiction upstream from Zanatepec in the municipality of San Miguel Chimalapa, agreed to rent their parcels to the Canadian company Minaurum Gold. According to local news reports, a coalition of activists and local government representatives in the region has petitioned Mexico's president elect, Andres Manuel López Obrador, for a formal consultation in line with international treaties on indigenous rights (Manzo 2018). At the same time, other activists argue that consultations themselves merely legitimize the dispossession of communities, due to the inherent power asymmetries between the parties (REMA 2019; see also Dunlap 2018b). This latter position was echoed to me in conversations with teachers from the Preparatoria por Cooperación Jose Martí.

\section{Regional and inter-ethnic coalitions}

The following examples demonstrate the (re)construction of pan-indigenous interests and values in connection with Indigenous cosmovisions/temporalities about sustainable resource use. In past decades, the Istmo region's largest social movements heavily emphasized claims to Zapotec culture and identity - the Zapotecs tended to view the neighboring Zoques and ikoots pejoratively as indios, and they treated any nonZapotecs as "outsiders" (Altamirano-Jiménez 2013: 195).

Looking beyond localism, the theorist Benjamin Maldonado advocates every Indigenous locality joining together into "one big community governed by principles of comunalidad." ${ }^{3}$ This proposal aims to have various localities "articulate themselves as pueblos... so that they may have discussions and make decisions with regards to education, health, infrastructure, etc. in their territory, and build a view towards the future" (Maldonado 2003). APOYO (whose very name evokes the "articulation" of which comunalistas like Maldonado speak) similarly emphasizes the future well-being of the Isthmus region and its multi-ethnic peoples. This cooperation is evident in the "broad-based effort to establish alliances" among ikotts and Zapotecs against wind energy parks, which began around 2013 (Lucio 2018: 97).

In late October of 2016, APOYO members hosted a meeting in the fishing community of San Francisco del Mar Pueblo Viejo (population 885), which lies on an inlet between the Superior Lagoon and the Gulf of Tehuantepec. APOYO held an informational meeting there, with an audience of 50 people (adults were all male, plus 10 male and 15 female high school students). Referred to by locals as "Pueblo Viejo", the village is about an hour's car ride from Ixhuatán. Its people reject the Spanish-derived label of Huave and refer to themselves in their own language as ikoots, which means "us." As we gathered under a fishing canopy, it became apparent that very few people in the audience had heard of the SEZs. As strong hot winds blew loudly, high school youth affiliated with the Prepa Jose Martí set up a digital projector. They played clips from a documentary (Hija de la Laguna) about an anti-mining movement in Peru's Cajamarma region, supplied by the civil society organization Ojo de Agua Comunicación.

Manuel of the Jose Martí School opened the meeting by appealing to Indigenous and peasants' rights: "We live in difficult times. Defenders of their rivers and lands have been killed throughout our nation. The government is planning a Special Economic Zone on our lands. This will directly impact our lives, mostly in indigenous areas." The meeting framed the SEZ in class terms and as a danger to resource sovereignty and public health. A main speaker from Centro de Derecho Humanos-Tepeyac (Tepeyac Human Rights Center), an NGO based about three hours away in Tehuantepec, stated:

\footnotetext{
${ }^{3}$ Translation from text: "Es justamente desde la comunalidad que se puede reorientar el rumbo de los pueblos indios, pero para ello se requiere que logren articularse como pueblos, es decir, encuentren las formas de vincularse todas las comunidades de cada grupo étnico para que puedan tener discusiones y decisiones sobre el territorio étnico, los proyectos abarcativos en cuanto a educación, salud, infraestructura, etcétera, y construir una mirada conjunta hacia el futuro" (Maldonado 2003).
} 
National capitalists want to liberalize the Port of Salina Cruz for export, and international capitalists want the region's raw materials. Power companies are paying families 8 pesos per square meter of land to install power transmission lines. The number of wind turbines will double. Then there's mining, the most damaging project of all. The local Ostuta River is in danger, since a dam is being proposed there in order to generate hydroelectricity for the mine. Just like the documentary shown on Peru, the mine is in the highlands of Zanatepec and would contaminate the people downstream.

Human rights organizers like Marcelino paint a picture of globalized capitalism's drive to integrate energy, raw materials and land under a commodity logic. Ruben Valencia of Ixtepec spoke next, linking the risks to community health with the question of Indigenous rights. His remarks served to alert his audience in Pueblo Viejo that the mining project has already come close to accessing his town's gold deposits, and that a mine in Ixtepec would affect lagoon communities like Pueblo Viejo:

The ancient Zapotecs of Ixtepec always knew that gold existed there: 1.2 million ounces, according to a Mexican newspaper. Like cancer, it's best to attack this problem early, before mining can get underway. The company needs 26 permits, and only two of those require direct permission from community members. Strong winds would bring cyanide dust not only to Ixtepec but to other pueblos, so you should organize for your own good, not just to help us.

Ruben also noted that the Indigenous customs retained in the Isthmus legitimize the collective rights of its people to have a voice in the future of their territory:

Since February, we've done 35 film projections and gotten 5,000 signatures against the mine. When we in the Comité Ixtepecano located a landmark in the mountains that marked the mining company's property, we led a march of 100 people up there to destroy the landmark (la mojonera), and it was mainly the women who destroyed it. People don't recognize that we're Indigenous and we have rights. The national criteria for being indigenous is not just language, it's also the food, the cultural elements, the communal assemblies of a people...

A round of commentary and questions ensued after the presentations and the documentary film showing concluded. One older ikoots man, a member of a local fishing cooperative, spoke about how the proposed projects would harm the economic livelihoods of the local population:

I'd like to participate. This information is very important. I'd like to talk to our municipal president and the council of elders (consejo ejecutivo de ancianos) about it. If the quality of our fish remains good, we won't have to depend on government welfare programs for income.

Ruben Valencia also cited a mining accident in northern Mexico to justify APOYO's stance that mining could never be made "sustainable":

The idea of sustainable development is exactly the kind of argument the companies use to gain support. Even if they could clean up the arsenic and cyanide, they would have to cut down all the forest just to open the mine. There has never been any experience of [sustainable development based on mining] in this country. Look at the Sonora River: the mining company never paid their fines for polluting the Sonora river with arsenic. We shouldn't fall for lies. 
Such appeals communicated that the Istmo must anticipate threats and prepare now, in order to avoid the fate of other mining-contaminated regions of Mexico. In this manner, thousands of sympathetic participants have become mobilized in defensive resistance against mining in a relatively short span of time (Manzo 2016).

A series of meetings in Ciudad Ixtepec (2.5 hours away from Pueblo Viejo, north of Juchitán, Figure 3) were held in mid-November 2016 by the Comité Ixtepecano. The city of Ixtepec has about 10,000 inhabitants, many of whom speak Zapotec and/or continue to follow Zapotec traditions, in spite of the fact that the installation of the Pan-American Highway and other development projects have urbanized the area. The meeting engaged residents who depend on agriculture (e.g. corn, sorghum, sesame) and small-scale cattle ranching on communal lands.

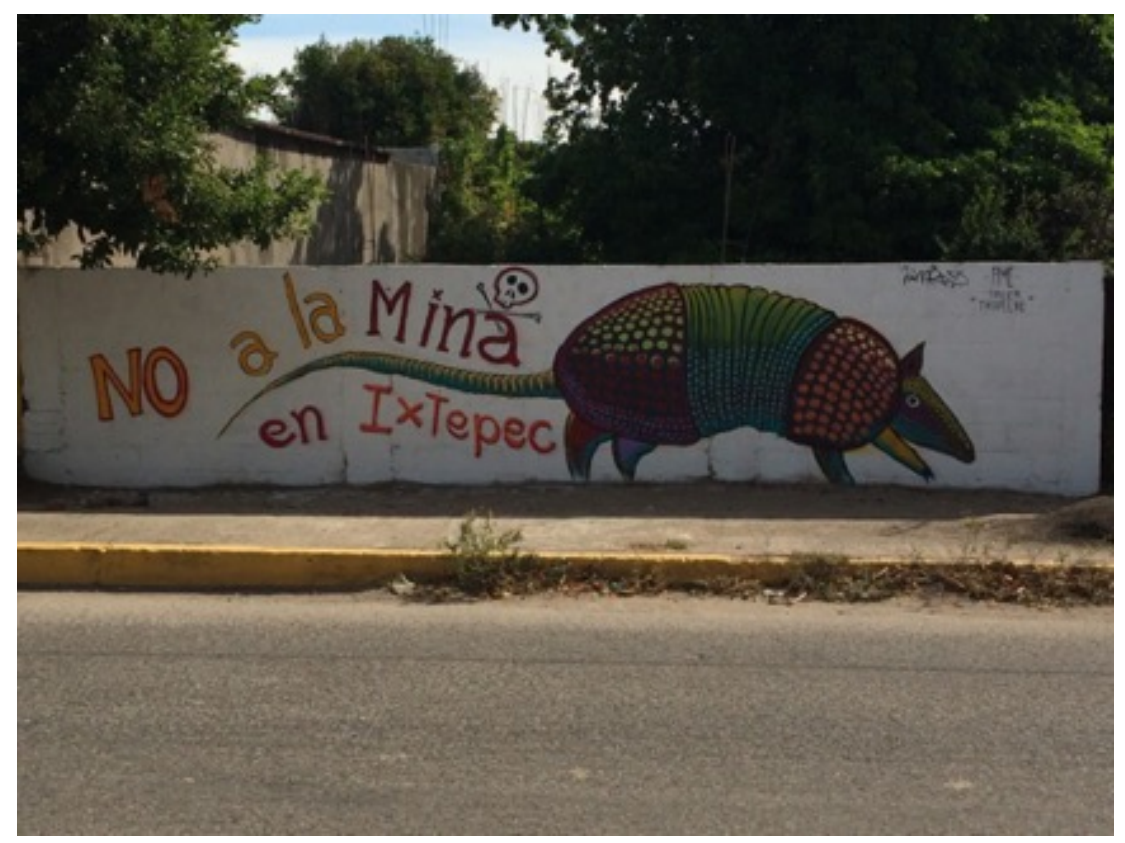

Figure 3: Mural "No a la Mina en Ixtepec." Photograph by author.

The local COCEI branch in Ixtepec, unlike most other COCEI offices today, is not affiliated with any political party. This independent stance establishes a symbolic link to the more radical traditions of that organization (Rubin 1997). About 40 people, mostly men over 30, congregated into the offices of the COCEI's women's committee (Ni Runni Binni, in Zapotec). The Comité Ixtepecano revealed that the Plata Real mining company has been trying to gain access to Ixtepec's land and minerals. Speakers pointed to how mining companies might further contribute to militarization and paramilitarization throughout the Istmo. ${ }^{4}$

Another meeting in Ixtepec took place at the local Sociedad Agricola (Agrarian Society) which democratically regulates irrigation for Ixtepec's fields and ranches. By basing their claims in the region's campesino identity, and in collective cultural standards of reciprocity that reflect the Guendaliza'a that progressive Ixtepecans uphold, meetings like this one served to coalesce a broad regional coalition. The crowd of about 70 people was overwhelmingly older adults and about evenly split between men and women. We listened to activists from Ixtepec speak about the proposed Lote Niza mining project, while we also heard men from Salina Cruz, Tehuantepec, Juchitán, La Hollaga, and Zanatepec talk about mining projects and the SEZ. Charismatic speakers recounted how the arrival of dams, illicit forestry and oil refining over the past several

\footnotetext{
${ }^{4}$ Dawn Paley (2014) has advanced the prescient argument that paramilitary violence in a given region, by generating panic and triggering military interventions, serves as a pretext to repress social movements and further privatize resources (see also Hristov et. al. forthcoming).
} 
decades have brought wealth to a relative few while impoverishing the natural resource base of the Isthmus (Lucio 2016). This reverberates with political ecology's theoretical literature on commodity frontiers (Moore 2011).

After the President of the Association of Ranchers (Asociación Ganadera) spoke, an elderly man gave his talk purely in Zapotec, then repeated it in Spanish. This man said he was a fisherman who worked in Salina Cruz long before the major PEMEX refinery had been built there:

The government said that the oil refinery wouldn't affect us. But yes, it did —all the beaches in Salina Cruz are now poor and polluted. It will be the same with the mine. It will affect you, compañeros! In Juchitán, for some fucking money, the people became divided and the wind parks came in. Our children will suffer this. It will affect you!

A coordinator of neighborhood committees (coordinador de colonias) from Salina Cruz then spoke about how the city he grew up in is now unrecognizable, but still poor. He ridiculed the government's notion that the jobs and investment from the refinery would turn Salina Cruz into a First World city:

Just go to la colonia petrolera [the oil quarter] where the people live. They say that we are against progress. But where is the progress? What the refinery did do was kill the fishing industry, and take the water. I know many communities nearby that still don't have electricity.

Marcelino of Centro de Derechos Humanos Tepeyac noted "The history of the Istmo is a history of dispossession, of failed infrastructure. But it's also a history of resistance." A campesino speaker in the audience interjected to connect environmental concerns with what he saw as government neglect of sustainable agriculture: "Why doesn't it rain like it used to? We don't have much water. As campesinos, water gives us life and a harvest. There's no support from the government for us. We're against mining." Many others applauded these remarks, which can be related to testimony that groundwater completely dried out in Juchitán for the first time in 2015-2016 (Dunlap 2019: 156). This is possibly a result of the large influx of wind turbines, against which campesinos in the region have levied and spread numerous grievances.

In proclaiming why the local COCEI branch joined the Comité Ixtepecano, Heriberto stated that "Ixtepec is an Indigenous and campesino community. We have native corn. We will fight so that these companies don't pollute it." Isabel Nunez, an older woman who is frequently quoted representing the Comité in both mainstream and alternative media, said that the only development she wanted is "one that's in accord with our lives and cultures."

Such calls to action reflect a collective identity rooted both in the legacy of the Mexican revolution's land reforms as well as in the ancestral cultures that predate it. But they are also advancing "the politics of time as a social movement" (Kirsch 2014: 216) by giving voice to Indigenous notions of temporality:

This is the territory of our ancestors. What we are defending is our right to continue our lives ( seguir con vida) here, and we want the territory to continue to be utilized by those who come after us. We don't need to offer any other justification for opposing gold extraction here. It's not even really about whether they take the gold or not. The territory is ours and we have to defend this right to life.

I would ask movement participants the question: "You're against the mines, but what kind of alternative is your movement for?" Respondents commonly answered, "We're for life itself" (La vida), by which they mean a specific set of material and symbolic relationships among people, as well as between human beings and the natural environment. This recalls Jaime Luna's (2010) perspective that comunalidad is "a way of understanding life as being permeated with spirituality, symbolism, and a greater integration with nature." It is both "a 
historical experience and a vibrant, present day set of behaviors, which are constantly renovated in the face of the social and economic contradictions generated by capitalist individualism" (Luna 2010: no pp.).

Activists are not unanimous over the exact meaning of comunalidad. Manuel Antonio Ruiz uses the term to capture "all facets of community life." By contrast, he views Guendaliza'a as having been "coined by the Isthmus Zapotec elite." Perhaps this is due to how Guendaliza'a downplays class differences through its traditional expectation that wealthier Zapotecs pay for seasonal festivities. Still, Manuel sees the two concepts as functionally similar (quizá sea lo mismo guendalizá que comunalidad). He tells me: "Comunalidad means living here and now with our own identity. For example, we want to continue being binnizá (Zapotec) but we also want to use tablets and cell phones. We want to keep existing as we are, and we are against transnationals changing our way of life."

It is not clear whether these strategies and frameworks will be capable of stopping mines from construction, and it is debatable whether the idealized constructs of indigeneity supported by NGOs offer systemic solutions to imperialism and climate change (Fabricant 2013). But the cosmovisions of comunalidad and Guendaliza'a represent one coherent response to globalized capital's rush to secure the "four cheaps": cheap food, fuel, labor and energy (Moore 2010, 2011). They also challenge the historic, entrenched dualism whereby Nature's alleged separation from Society severs social justice from environmental justice. Since much of the Istmo's population readily identifies with a historic oppositional culture undergirded by reciprocity, comundalidad has become a defensive strategy that coheres various regions, social strata, ethnic groups and types of activists for the protection of land, territory and natural resources.

\section{Conclusions}

These vignettes illustrate how the grievances, goals, and strategic repertoires developed by leading activists in the Isthmus of Tehuantepec have elaborated the region's latent oppositional culture into a more coherent oppositional consciousness (Morris 1992), or consciencia. Tetreault (2019: 89) is correct that mining can be interpreted through the lens of class struggle against dispossession, of distributional issues over the burdens of pollution, or cultural valuations about the symbolic value of nature. While all three of these elements interpenetrate in the case of the Isthmus and its most recent anti-mine organizing, cultural questions remain highly salient.

Prior efforts to bridge the Istmo's ethnic divides have blossomed into a new phase of struggle against the threat of mega-mines. Unlike the iconic movement against the San Xavier mine in San Luis Potosí beginning in the late 1990s (Tetreault 2019), the Isthmus was already a place where indigeneity and political movements around ethnic self-determination and environmental issues had been centered, long before local organizations became aware of mining company contracts. Present-day anti-mine networks grow out of at least two decades of previous organizing against a massive multi-site wind energy project that has been replete with ontological struggles over cultural valuation (Ávila-Calero 2017: 999; Dunlap 2018d; Lucio 2018), while expanding upon the lived memory of the COCEI movement in the early 1980s. However, while the COCEI were centered among Zapotecs in Juchitán de Zaragoza, today's Zapotecs influenced by comunalidad lay claim to a pan-Indigenous vision that seeks relationships of solidarity with the Istmo's other marginalized ethnic groups.

Perhaps more so than many other regions of Mexico, the Isthmus has a strong communal tradition "expressed through land tenure regimes, cultural identity and political practices" (Ávila-Calero 2017: 1005). One interesting caveat to this is that none of the towns studied in this article are governed according to usos $y$ costumbres, the traditional system of Indigenous governance that prevails in 418 of Oaxaca's 570 municipalities (Aquino Centeno 2013). This customary assembly method of making local decisions and electing local leaders serves as an "institutional basis" for struggle against extractive projects (Tetreault et al. 2018: 24). Anti-mine actors in the towns of Ixtepec, Ixhuatán and Zanatepec do not have this institutional framework to rely upon. Instead, they connect with civil society groups like REMA and Tepeyac Human Rights Center while seeking to rebuild an Indigenous culture of cooperation within and between pueblos (Fenelon and Hall 2008).

The Istmo is increasingly stratified by class, industry, political party and occupation. Even so, participants in the regional APOYO coalition, together with unions of ejidos and local environmentalists, have built a multi-class network of urbanized professionals as well as rural producers who revere nature for its use- 
value. In Ixtepec, I was told that even campesinos who support the PRI party which promulgated the SEZ are against the mining project in the mountains. This echoes reports that in the town of Alvaro Obregón, two opposed factions who violently disagreed with one another over whether to accept a wind energy project both voted by assembly in favor of directly aiding the anti-mine organizations in neighboring towns, out of common environmental concerns for their lagoon (Dunlap 2019: 156). Similarly, my respondents asserted that they want the land and territory maintained "not just for we who are now old", but for their children and grandchildren.

It merits noting that the current national government in Mexico under President López Obrador appears to be retracting its support for the SEZ in the south of the country-except for the Trans-Isthmus Corridor which connects Oaxaca's Isthmus with Veracruz. This again suggests the strategic geographic importance of the Isthmus to the Mexican political economy and to global accumulation in the current era. In place of an SEZ, the government is now floating the idea of a "free zone" (Zona Libre) with seven "industrial parks" in the Isthmus of Tehuantepec. Thus, the Isthmus SEZ is being renamed yet again, but the race for cheap nature endures. The new "free zone" project will rely upon tapping "all of the raw materials in the area", according to Rafael Marín Mollinedo, a federal administrator of the SEZ (González 2019). ${ }^{5}$ The Tehuantepec Isthmus remains a center of raw materials extraction and multinational investments, regardless of the change in presidential administration. Hence, its ongoing movements in defense of "life and territory" may go on to impact Mexico's national developmental policies and its national debates on extractive megaprojects.

As more comparative research is done on the ethnic and cultural dimensions of resource extraction conflicts, it would be beneficial to critically integrate native standpoints like comunalidad and Guendaliza'a into our analytical frameworks. At the same time, future scholarship should study how advocates of these reimagined Indigenous cosmovisions navigate differences of ethnicity, class, gender, language and geography as they seek to build defensive movements.

\section{References}

Acosta, R.A.M. 2014. Wejën Kajën: la Comunalidad, una vision contemporanea de resistencia a partir de los modos de vida de los Pueblos Indigenas. Masters Thesis. National Autonomous University of Mexico.

Arce, M. 2014. Resource extraction and protest in Peru. Pittsburgh: University of Pittsburgh Press.

Arce, M. 2016. The political consequences of mobilizations against resource extraction. Mobilization: an International Quarterly 21(4): 469-483.

Altamirano-Jiménez, I. 2013. Indigenous encounters with neoliberalism: place, women, and the environment in Canada and Mexico. Vancouver: University of British Columbia Press.

Aquino Centeno, S. 2013. Interrogando la costumbre y la legislación Indígena: contribuciones y horizontes de la antropología jurídica en Oaxaca. Nueva Antropología 26(78): 87-117.

Atkinson, R., and J. Flint. Accessing hidden and hard-to-reach populations: snowball research strategies. Social Research 33(1): 1-4.

Ávila-Calero, S. 2017. Contesting energy transitions: wind power and conflicts in the Isthmus of Tehuantepec. Journal of Political Ecology 24(1): 992-1012.

Ávila-Calero, S. 2016. Victor M. Toledo: 'political ecology is here to stay.' Ecología Política. [accessed June 26 2019].

https://voicesmotherearth.blogspot.com/p/ecologia-politica-sofia-avila-calero.html

Bárcenas, F.L. 2017. La vida o el mineral: los cuatro ciclos del despojo minero en México. Madrid: Akal.

Bárcenas, F.L., and M.M.E. Galicia. 2011. El mineral o la vida: la legislación minera en México. Centro de Orientación y Asesoría a Pueblos Indígenas.

Barkin, D. 2013. La minería como factor de desarrollo en la Sierra Juárez de Oaxaca: Una valoración ética. Problemas del desarrollo 44(172): 123-144.

\footnotetext{
5 Similarly, Arce (2016) shows how "intransigent" anti-mining protests in Peru have had national and international ramifications, partly because Peru's economy is so structurally dependent upon resource extraction.
} 
Bebbington, A.J., D. Humphreys Bebbington, J. Bury, J. Lingan, J. Pablo Muñoz, and M. Scurrah. 2008. Mining and social movements: struggles over livelihood and rural territorial development in the Andes. World Development 36(12): 2888-2905.

Benford, R.D. 1997. An insider's critique of the social movement framing perspective. Sociological Inquiry 67(4): 409-430.

Binford, L. 1985. Political conflict and land tenure in the Mexican isthmus of Tehuantepec. Journal of Latin American Studies 17(1): 179-200.

Blaser, M. 2013. Notes towards a political ontology of 'environmental' conflicts. In Green, L. (ed.). Contested ecologies: dialogues in the South on nature and knowledge. Cape Town: HSRC Press. Pp. 13-27.

Bunker, S.G., and P.S. Ciccantell. 2005. Globalization and the race for resources. Baltimore: Johns Hopkins University Press.

Campbell, H. 1994. Zapotec renaissance: ethnic politics and cultural revivalism in southern Mexico. Albuquerque: University of New Mexico Press.

Campbell, H., L. Binford, M. Bartolomé and A. Barabes. 1993. Zapotec struggles: histories, politics and representations from Juchitán, Oaxaca. Washington: Smithsonian Institution Press.

Charmaz, K. 2004. Premises, principles, and practices in qualitative research: revisiting the foundations. Qualitative Health Research 14(7): 976-993.

Chaca, R. 2015. Dicen no a proyecto minero en San Miguel Chimalapa. [accessed July 12018 ]. http://old.nvinoticias.com/istmo/general/agropecuarias/299280-dicen-no-proyecto-minero-san miguel chimalapa

Comité Ixtepecano. 2016. Un breve recorrido por la lucha en Ixtepec Oaxaca contra proyecto de muertellamado

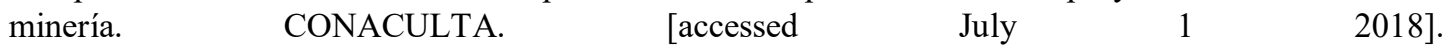
http://www.movimientom4.org/wpcontent/docs/recorridopor-la-lucha-en-ixtepec-contra-el-proyectode-muerte-llamando-mineria-1.pdf

Delgado, J.O. 2002. El Plan Puebla-Panamá y la globalización neoliberal. Aportes: Revista de la Facultad de Economía-Buap VII(21): 137-155.

Díaz, F., S.R. Hernández and R.C. Jiménez. 2007. Floriberto Díaz: escrito: comunalidad, energía viva del pensamiento mixe. Mexico City: UNAM.

Dore, E. 2000. Environment and society: long-term trends in Latin American mining. Environment and History 6(1): 1-29.

Downey, L., E. Bonds and K. Clark. 2010. Natural resource extraction, armed violence, and environmental degradation. Organization and Environment 23: 417-445.

Dunlap, A. 2018a. 'A bureaucratic trap:' Free, Prior and Informed Consent (FPIC) and wind energy development in Juchitán, Mexico. Capitalism Nature Socialism 29(4): 88-108.

Dunlap, A. 2018b. Counterinsurgency for wind energy: the Bíi Hioxo wind park in Juchitán, Mexico. The Journal of Peasant Studies 45(3): 630-652.

Dunlap, A. 2018c. The 'solution' is now the 'problem:' wind energy, colonisation and the 'genocide-ecocide nexus' in the Isthmus of Tehuantepec, Oaxaca. The International Journal of Human Rights 22(4): 550573.

Dunlap, A. 2018d. Insurrection for land, sea and dignity: resistance and autonomy against wind energy in Álvaro Obregón, Mexico. Journal of Political Ecology 25(1): 120-143.

Dunlap, A. 2019. Revisiting the wind energy conflict in Gui'Xhi'Ro/Álvaro Obregón: interview with an indigenous anarchist. Journal of Political Ecology 26(1): 150-166.

Escalón, P.E. and G.E González. 2017. La escuela como actor social en las luchas contra el extractivismo: Prácticas político-pedagógicas desde la educación comunitaria en Oaxaca, México. Diálogos sobre Educación: Temas Actuales en Investigación Educativa 8(15).

Escobar, A. 2006. Difference and conflict in the struggle over natural resources: a political ecology framework. Development 49(3): 6-13. 
Escobar, A. 2008. Territories of difference: place, movements, life, redes. Durham: Duke University Press.

Fabricant, N. 2013. Good living for whom? Bolivia's climate justice movement and the limitations of indigenous cosmovisions. Latin American and Caribbean Ethnic Studies 8(2): 159-178.

Fenelon, J.V. and T.D. Hall. 2008. Revitalization and indigenous resistance to globalization and neoliberalism. American Behavioral Scientist 51(12): 1867-1901.

Fresh Plaza (anonymous). 2016. Mexico: Oaxaca exports 32,000 tons of mango to the US and Canada. [Accessed March 2 2019]. https:/www.freshplaza.com/article/2164810/mexico-oaxaca-exports-32000-tons-of-mango-to-the-us-and-canada/

Carrasco, M.E.F. 2018. La comunalidad como base para la construcción de resiliencia social ante la crisis civilizatoria. Polis Revista Latinoamericana 11(33): 195-218.

Global Witness. 2014. Deadly environment: the dramatic increase in killings of environmental and land defenders. London: Global Witness.

Gómez, F. D. 2001. Comunidad y comunalidad. La Jornada Semanal 314(12).

González, S.G. 2019. Lanzan pronunciamiento en rechazo al Corredor Transístmico. La Jornada. [Accessed May 21 2019] https:/www.jornada.com.mx/ultimas/2019/04/25/lanzan-pronunciamiento-en-rechazoal-corredor-transistmico-5447.html

González Licón, E. 1990. Los zapotecas y mixtecas: tres mil años de civilización precolombina. México: Consejo Nacional para la Cultura y las Artes; Milan: Jaca Book.

Gudynas, E. 2009. Diez tesis urgentes sobre el nuevo extractivismo. Extractivismo, Politica y Sociedad. Quito: CAAP and CLAES. Pp. 187-225.

Guenther, K.M. 2009. The politics of names: rethinking the methodological and ethical significance of naming people, organizations, and places. Qualitative Research 9(4): 411-421.

Harrup, A. 2016. Mexico to create economic zones to develop poor southern states. The Wall Street Journal. [Accessed December 12, 2016]. https://www.wsj.com/articles/mexican-president-signs-law-for-specialeconomic-zones-1464730260

Harvey, D. 2001. Spaces of capital: towards a critical geography. London: Routledge.

Heidrich, P. 2016. Determinants, boundaries, and patterns of Canadian mining investments in Latin America (1995-2015). Latin American Policy 7(2): 195-214.

Hortensia, U.H.R. 2014. Vivir la mina: el conflicto minero en San José del Progreso y sus efectos cotidianos en la vida individual y la existencia colectiva; rupturas, contrastes, reconstrucciones y resistencias. M.A. Thesis. Oaxaca, Mexico: CIESAS.

Hristov, J., J. Sprague-Silgado and A. Tauss. (forthcoming). The political violence of capital: paramilitary formations in global perspective. London: Routledge.

Jimenez Lopez, G. 2015. Historia de Juchitán. Oaxaca: Diamante.

Kirsch, S. 2014. Mining capitalism: the relationship between corporations and their critics. Berkeley: University of California Press.

Kojola, E. 2019. Indigeneity, gender and class in decision-making about risks from resource extraction. Environmental Sociology 5(2): 130-148.

Leach, D. 2013. Prefigurative politics. In Snow, D.A., D. Della Porta, P.G. Klandermans and D. McAdam (eds,). The Wiley-Blackwell encyclopedia of social and political movements. London: Wiley Blackwell.

Levien, M. 2012. The land question: special economic zones and the political economy of dispossession in India. The Journal of Peasant Studies 39(3-4): 933-969.

Lucio, C. 2016. Conflictos socioambientales, derechos humanos y movimiento indígena en el Istmo de Tehuantepec. Zacatecas: Universidad Autonoma de Zacatecas Press.

Lucio, C. 2018. Winds of resistance in the Isthmus of Tehuantepec. In D. Tetreault, C. McCulligh and C. Lucio (eds.). Social environmental conflicts in Mexico. Cham: Palgrave Macmillan. Pp. 81-107.

Luna, J.M. 2010. Eso que llaman comunalidad. Mexico City: Consejo Nacional para la Cultura y las Artes. 
Maldonado, B. 2003. La comunalidad indígena. Segunda edición cibernética. [Accessed March 15 2009]. http://www.antorcha.net/biblioteca_virtual/politica/comunalidad/comunalidad.html.

Maldonado, B. 2010. Comunidad, comunalidad y colonialismo en Oaxaca, México: la nueva educación comunitaria y su contexto. $\mathrm{PhD}$ dissertation. Leiden: Leiden University.

Manzo, C. 2008. Asimilación y resistencia: raíces coloniales de la autonomía indígena en el sur del istmo de Tehuantepec. Estudios Sociales Nueva Época 3: 107-124.

Manzo, C. 2011. Comunalidad, resistencia indigena y neocolonialismo en el Istmo de Tehuantepec, siglos XVI$X X I$. Mexico: Ce-Acatl.

Manzo, D. 2016. En Zanatepec se unen y protestan contra la mineria. Istmo Press [Accessed March 152019 ]. http://www.istmopress.com.mx/istmo/en-zanatepec-se-unen-y-protestan-contra-la mineria/

Manzo, D. 2018. Declaran "libre de mineria" a Zanatepec, Oaxaca. La Jornada 29 December. [Accessed March 1 2019] https://www.jornada.com.mx/2018/12/29/estados/021n4est?fbclid=IwAR2OihRfLwt4T0

Martínez, Á.Á. and M.A. Ochoa. 2017. Mexico's Special Economic Zones: regional development or more neoliberal reform? Committee on U.S.-Latin American Relations. [accessed September 15 2018] https://cuslar.org/2017/01/11/mexicos-special-economic-zones-regional-development-or-moreneoliberal-reform/

Martinez-Alier, J, H. Healy, L. Temper, M. Walter, B. Rodriguez-Labajos, J.F. Gerber and M. Conde. 2011. Between science and activism: learning and teaching ecological economics with environmental justice organisations. Local Environment 16 (1): 17-36.

Martinez-Alier, J., G. Kallis, S. Veuthey, M. Walter and L. Temper. 2010. Social metabolism, ecological distribution conflicts, and valuation languages. Ecological Economics 70(2): 153-158.

Martínez Alier, J. and M. Walter. 2016. Social metabolism and conflicts over extractivism. In de Castro, F., B. Hogenboom and M. Baud (eds.). Environmental governance in Latin America. London: Palgrave Macmillan. Pp. 58-85.

Matias, P. 2016. "Toman" minera en San José del Progreso, Oaxaca; exigen salida de empresa canadiense. Proceso [Accessed March 1 2019]. https://www.proceso.com.mx/439883/toman-instalaciones-mineraen-san-jose-del-progreso-oaxaca

Meyer, D.S. 1990. A winter of discontent: The nuclear freeze and American politics. Santa Barbara: ABC CLIO.

Moore, J. 2000. Sugar and the expansion of the early modern world economy: commodity frontiers, ecological transformation, and industrialization. Review (Fernand Braudel Center) 23(3): 409-433.

Moore, J.W. 2010. Cheap food and bad money: food, frontiers, and financialization in the rise and demise of neoliberalism. Review (Fernand Braudel Center), 33(2-3): 225-261

Moore, J.W. 2011. Ecology, capital, and the nature of our times: accumulation and crisis in the capitalist world ecology. Journal of World-Systems Research 17(1): 107-146.

Moore, J.W. 2015. Capitalism in the web of life: ecology and the accumulation of capital. New York: Verso.

Morosin, A. 2019. Confronting dispossession: environmental justice, indigenous mobilization, and gender relations in the Isthmus of Tehuantepec. PhD Dissertation. Riverside: University of California Riverside.

Morosin, A. 2020. (forthcoming) Paramilitaries in Oaxaca, Mexico: enforcing accumulation in a geo-strategic region. In Hristov, J., J. Sprague-Silgado and A. Tauss (eds.). The political violence of capital: paramilitary formations in global perspective. London: Routledge.

Morris, A. 1992. Political consciousness and collective action. In Morris, A.D., C.A. Morris and N. Braine (eds.). Oppositional consciousness: the subjective roots of social protest. Chicago: University of Chicago Press.

Nahmad, S., A. Nahón and R. Langlé. 2011. El impacto social del recurso eolico. Informe final para el Consejo Oaxaqueño de Ciencia y Tecnología. CIESAS-Unidad Pacifico Sur.

Narchi, N.E. 2015. Environmental violence in Mexico: a conceptual introduction. Latin American Perspectives 42(5): 5-18.

Paley, D. 2014. Drug war capitalism. Oakland: AK Press. 
Partridge, T. 2017. Resisting ruination: resource sovereignties and socioecological struggles in Cotopaxi, Ecuador. Journal of Political Ecology 24(1): 763-776.

Payán, T. and G. Correa-Cabrera. 2014. Land ownership and use under Mexico's energy reform. Issue Brief. Houston: Baker Institute, Rice University.

Pellow, D.N. 2017. What is critical environmental justice? London: Wiley.

Porto, M.F. and T. Pacheco. 2009. Conflitos e injustiça ambiental em saúde no Brasil. Tempus Actas de Saúde Coletiva 4(3): 26-37.

Ramos, G.C. 2012. Extractivismo minero, conflicto y resistencia social. Realidad Económica 265(1): 60-84.

Red Mexicana de Afectados Por La Mineria (REMA), 2019. Comunicado. Las consultas "buenas" no existen: basta de engañar a los pueblos. [Accessed April $1 \quad 2019$ http://www.remamx.org/2019/04/comunicado-las-consultas-buenas-no-existen-basta-de enganar-a-los-pueblos/

Rendón Monzón, J.J. 2003. La comunalidad: modo de vida en los pueblos indios. Mexico: Educal.

Rocheleau, D.E. 2015. Networked, rooted and territorial: green grabbing and resistance in Chiapas. Journal of Peasant Studies 42(3-4): 695-723.

Rodriguez, A. 2017. Mexico creates first special economic zones. BN America. [accessed April 28 2018]. https:/www.bnamericas.com/en/news/infrastructure/mexico-creates-their-first-specialeconomiczones1

Rubin, J.W. 1994. COCEI in Juchitán: grassroots radicalism and regional history. Journal of Latin American Studies 26(1): 109-136.

Rubin, J.W. 1997. Decentering the regime: ethnicity, radicalism, and democracy in Juchitán, Mexico. Durham: Duke University Press.

Sigler, T.J. 2014. Panama's special economic zones: balancing growth and development. Bulletin of Latin American Research 33(1): 1-15.

Snow, D.A. and D. M. Moss. 2014. Protest on the fly: toward a theory of spontaneity in the dynamics of protest and social movements. American Sociological Review 79(6): 1122-1143.

SIPAZ. 2016. Oaxaca: pobladores en Ixtepec rechazan proyecto minero. 11 July [Accessed March 202019 ]. https://sipaz.wordpress.com/2016/07/11/oaxaca-pobladores-en-ixtepec-rechazan proyecto-minero/

Stavenhagen, R. 1981. Between underdevelopment and revolution: a Latin American perspective. New Delhi: Abhinav Publications.

Stephen, L. 1998. Between NAFTA and Zapata: responses to restructuring the commons in Chiapas and Oaxaca, Mexico. In Goldman, M. (ed.). Privatizing nature: political struggles for the global commons. London: Pluto Press.

Stoltenborg, D. and R. Boelens. 2016. Disputes over land and water rights in gold mining: the case of Cerro de San Pedro, Mexico. Water International 41(3): 447-467.

Temper, L., Del Bene, D., \& J. Martinez-Alier. 2015. Mapping the frontiers and front lines of global environmental justice: the EJAtlas. Journal of Political Ecology 22(1): 255-278.

Tetreault, D. 2015. Social environmental mining conflicts in Mexico. Latin American Perspectives 42(5): 4866.

Tetreault, D. 2016. Free-market mining in Mexico. Critical Sociology 42(4-5): 643-659.

Tetreault, D. 2019. Resistance to Canadian mining projects in Mexico: lessons from the lifecycle of the San Xavier Mine in San Luis Potosí. Journal of Political Ecology 26(1): 84-104.

Tetreault, D., C. McCulligh and C. Lucio. 2018. An introduction to social environmental conflicts and alternatives in Mexico. In Tetreault, D., C. McCulligh and C. Lucio (eds.). Social environmental conflicts in Mexico. London: Palgrave Macmillan. Pp. 3-41.

Toledo, V.M. 2015. Ecocidio en México: la batalla final es por la vida. Barcelona: Grijalbo. 
Toledo, V.M., D. Garrido and N. Barrera-Bassols. 2015. The struggle for life: socio environmental conflicts in Mexico. Latin American Perspectives 42(5): 133-147.

Urkidi, L. and Walter, M., 2011. Dimensions of environmental justice in anti-gold mining movements in Latin America. Geoforum 42(6): 683-695.

Vásquez, X.N.V. 2008. Wejën-Kajën. Las dimensiones del pensamiento y generación del pensamiento comunal. Mixe, Oaxaca: H. Ayuntamiento de Tlahuitoltepec.

Wilson, J. 2014. The violence of abstract space: contested regional developments in southern Mexico. International Journal of Urban and Regional Research 38(2): 516-538.

Wolfe, P. 2006. Settler colonialism and the elimination of the native. Journal of Genocide Research 8(4): 387409.

Veltmeyer, H. and P. Bowles. 2014. Extractivist resistance: the case of the Enbridge oil pipeline project in northern British Columbia. The Extractive Industries and Society 1(1): 59-68.

Veltmeyer, H., J.F. Petras, V. Albuja and L. Chapple. 2014. The new extractivism: a post neoliberal development model or imperialism of the twenty-first century? London: Zed.

Yates, L. 2015. Rethinking prefiguration: alternatives, micropolitics and goals in social movements. Social Movement Studies 14(1): 1-21. 